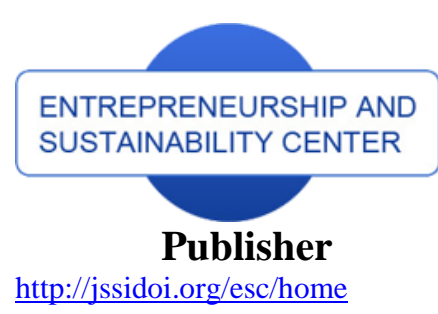

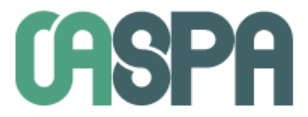

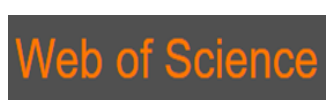

1 Clarivate

Analytics

\title{
COMPARATIVE ANALYSIS OF COMPANY PERFORMANCE EVALUATION METHODS
}

\author{
Judita Narkunienè $\dot{1}^{\text {, Aurelija Ulbinaitè }}{ }^{2}$ \\ ${ }^{1,2}$ Vilnius University, Faculty of Economics and Business Administration

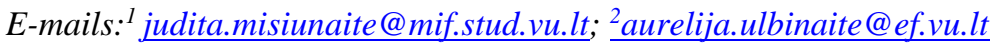

Received: 19 March 2018; accepted 24 April 2018; published 30 September 2018

\begin{abstract}
The evaluation of a company's performance is an integral part of the management of every company, which allows determining the impact of business management decisions on the performance results, as well as the direction of the results and the decisions that need to be made to improve them. Traditionally, a company's performance is evaluated on the basis of an analysis of financial performance indicators, but it is noted that in today's dynamic business environment the timely control of the performance is crucial, thus, there is an increasing attention on non-financial performance indicators. The aim of the article is to investigate and compare the modern methods for company performance evaluation that are based on the analysis of financial and non-financial performance indicators. The research is carried out using systematic analysis of scientific literature, comparison, and aggregation methods. First of all, the article unfolds the essence of the concept of the company performance evaluation and highlights the differences between traditional and modern performance evaluation systems. Moreover, the advantages of non-financial performance indicators are compared with financial indicators. Furthermore, a classification scheme for performance evaluation methods is provided; by identifying their main advantages and disadvantages the most popular and widely used modern performance evaluation methods are overviewed: economic value added method, balanced scorecard, performance prism, performance pyramid, six-sigma model and multi-criteria company performance evaluation method. Finally, according to certain criteria, a comparative analysis of the latter methods is performed. The comparative analysis confirms that non-financial performance indicators complement financial indicators; therefore, in the process of a company's performance evaluation, modern performance evaluation methods, combining financial and non-financial performance indicators and allowing the performance to be evaluated both quantitatively and qualitatively, should be used. However, there is no single method that would be appropriate for all companies, so further work can be targeted at establishing a multi-criteria performance evaluation method that would satisfy the needs of a particular business' activity and targets for evaluation.
\end{abstract}

Keywords: company performance evaluation, modern performance evaluation methods, financial indicators, non-financial indicators

Reference to this paper should be made as follows: Narkunienė, J.; Ulbinaite, A. 2018. Comparative analysis of company performance evaluation methods, Entrepreneurship and Sustainability Issues 6(1): 125-138. http://doi.org/10.9770/jesi.2018.6.1(10)

JEL Classifications: L25, M21

\section{Introduction}

Business performance evaluation is an inseparable management part of a company without which it would be difficult to define the impact of business management decisions, the direction of its activity results and the decisions that must be taken to improve the results. Traditionally, business results are evaluated following 


\section{The International Journal}

ENTREPRENEURSHIP AND SUSTAINABILITY ISSUES

ISSN 2345-0282 (online) http://jssidoi.org/jesi/

2018 Volume 6 Number 1 (September)

http://doi.org/10.9770/jesi.2018.6.1(10)

company's financial data that are given in the financial reports; however, it can be noted that company's financial information is insufficient for more and more companies and, striving to better unfold causal relationships between management decisions and final activity results, a huge attention is drawn on a company's non-financial performance indicators.

The relevance of non-financial information is underlined by European Commission and Board in their published directives regarding disclosure of non-financial information of certain huge companies and groups (2013/34/ES and 2014/95/ES). The directives state that the disclosure of non-financial information is a very significant step in proceeding with the sustainable global economy, where the long-term profitability is under combination with social justice and environmental protection, taking into account that the disclosure of non-financial information helps evaluating, monitoring and managing results of companies' performance results and their impact on society (Europos..., 2014). The directive states that, starting from $1^{\text {st }}$ of January 2017, huge companies of European Union countries members (having more than 500 employees) should involve a non-financial report in their management report, where, as much as it is necessary for understanding company's changes, performance results, status, and the impacts of its activity, the information at least regarding environmental issues, social and staffrelated issues, and the aspects regarding respect to human rights, fight against corruption and briberies must be provided. This directive could be an incentive to monitor and fix the non-financial performance indicators not only for huge companies, but also for small and middle-sized ones, since it is stated that this kind of information could increase the trust of investors and consumers.

The significance of non-financial indicators is as well highlighted in the works of researchers of the last decades (Abdel-Maksoud et al., 2005, Lau et al., 2005, Cardinaels et al., 2010, Kotane et al., 2011, Milost, 2013, Kotane, 2015, Ahmad et al., 2016, Modi, 2016), where the modern company performance evaluation systems are presented and discussed. Most of company performance evaluation methods are oriented to business strategies which are not limited to profitability magnification, therefore, the spectrum of performance evaluation is expanded beyond the boundary of financial information by involving the information about both consumer and employee satisfaction, execution of processes, growth possibilities and similar. It is worth to note that the necessity of monitoring and evaluating the non-financial indicators is highlighted in evaluation of performance results of manufacturing companies, since there it is most often one has to manage many processes, which are complicated to be evaluated following barely the financial information. Therefore, striving to evaluate manufacturing company performance results, it is significant to apply the methods that could involve both financial and non-financial information, related to processes, employees and similar.

The goal of this article is to review and compare the modern company performance evaluation methods, justified by financial and non-financial performance indicators analysis. This research is conducted using the methods of scientific research literature analysis, comparison and aggregation of research information.

\section{The concept of company's performance evaluation}

Performance evaluation is defined ambiguously in the research literature (see Table 1). Some authors (Neely, Gregory, Platts (1995), Marshall, Wray, Epstein, Grifel (1999), Najmi, Kehoe (2001)) perceive performance evaluation as a process, where company's results are evaluated quantitatively by analysing certain indicators. On the other hand, the authors of the latter decade (Moullin (2007), Klovienè (2012), Choong (2013), Peleckis (2013)) note that performance evaluation should not necessary be quantitative. Managing quality evaluation, defining customer value and value created for other interested parties, disclosure of common business situation, and raising further goals for improvement are significant. Out of a list of definitions in research literature, the most resumptive and exact perception of performance evaluation is provided by Klovienè (2012): it is a broad and multifunctional process that combines the key performance indicators which help evaluating performance, 
guarantees company management process, value creation, adjustment, speedy reaction, and enables improvement and growth of a company.

Table 1. The concept of performance evaluation

\begin{tabular}{|l|l|}
\hline \multicolumn{1}{|c|}{ Author } & \multicolumn{1}{c|}{ Definition } \\
\hline $\begin{array}{l}\text { Neely, Gregory, Platts } \\
\text { (1995) }\end{array}$ & $\begin{array}{l}\text { The process of quantifying the effectiveness and the efficiency of actions } \\
\text { with a set of metrics }\end{array}$ \\
\hline $\begin{array}{l}\text { Marshall, Wray, Epstein, } \\
\text { Grifel (1999) }\end{array}$ & $\begin{array}{l}\text { Development of indicators and collection of data to describe, report on and } \\
\text { analyse performance }\end{array}$ \\
\hline Najmi, Kehoe (2001) & $\begin{array}{l}\text { Monitoring, management and improvement of measurable criteria that tell } \\
\text { how the tasks were fulfilled and motivate to perform in order to achieve the } \\
\text { goals of the company }\end{array}$ \\
\hline Moullin (2007) & $\begin{array}{l}\text { The organization management quality rating and determination of value for } \\
\text { customers and other interested parties. }\end{array}$ \\
\hline Kloviene (2012) & $\begin{array}{l}\text { A broad and multifunctional process combining key performance } \\
\text { indicators to help evaluate business performance, ensuring management } \\
\text { process, value creation, adaptability and quick reaction, helping the } \\
\text { company to improve and grow. }\end{array}$ \\
\hline Choong (2013) & $\begin{array}{l}\text { It is concerned with improvement in which its implementation requires } \\
\text { target or goal, so that measurement and evaluation ca be made against } \\
\text { appropriate benchmark }\end{array}$ \\
\hline Peleckis (2013) & $\begin{array}{l}\text { A clock showing the current business situation and trends in its } \\
\text { development, helping the company to decide where to go }\end{array}$ \\
\hline
\end{tabular}

Source: made by the authors

Under dynamic business environment, performance control plays an especially significant role, thanks to which one can observe ongoing changes and timely react to them. For a long time, performance evaluation has been conducted based on financial activity information by analysing indicators of profitability, liquidity, solvency and other financial ones. Such an evaluation has formed a traditional view that is as well followed by businesses nowadays. On the other hand, under modern economic environment, it is more and more often that the traditional performance evaluation methods receive criticism. Christauskas et al. (2009) state that the traditional performance evaluation systems do not help solving managerial problems that arise under the context of dynamic business conditions; these systems are not capable to evaluate real factors that create a value. For this reason, the modern performance evaluation methods have a higher and higher demand in business performance evaluation.

\section{The advantages of modern performance evaluation methods as compared to traditional ones}

In the beginning of 21st age, formation of strategies and rising of goals for implementation of the strategy has become an inseparable part of strategic business management. Certainly, business strategies are not restricted to barely profit increase, therefore, the evaluation of performance results cannot be limited to traditional evaluation methods based on the analysis of financial performance indicators. As a counterbalance for the traditional performance evaluations systems, striving to join internal and external indicators, financial and non-financial indicators, long-term and short-term performance indicators, modern performance evaluation systems were created (Adomavičiūtè, 2011). According to Kučinskienė et al. (2015), a complex viewpoint towards adapting new strategic management principles in a company's performance processes under the period of dynamic and heavily forecasted changes should help companies properly prepare management decisions and guarantee successful continuation of their performance. 
The International Journal

ENTREPRENEURSHIP AND SUSTAINABILITY ISSUES

ISSN 2345-0282 (online) http://jssidoi.org/jesi/

2018 Volume 6 Number 1 (September)

http://doi.org/10.9770/jesi.2018.6.1(10)

De Toni and Toncia (2001) distinguished the essential differences between traditional and modern performance evaluation systems (see Table 2). According to these authors, the traditional performance evaluation systems are oriented to profit and based on performance cost and efficiency analysis. With these systems, one strives to evaluate the results of the period in the past by calculating individual financial indicators and comparing them to the defined standard values. Differently from the traditional systems, the modern performance evaluation systems are oriented to consumers and satisfaction of their needs and are based on company's created value. With these systems, one has an intention not only to evaluate results of the period in the past, but also to define reasons that led to these results and to foresee steps to improve the future results. For this purpose, not individual indicators, but sets of key indicators that include various crosscuts of performance are evaluated.

Table 2. Comparison of the principles of traditional and modern performance evaluation methods

\begin{tabular}{|l|l|}
\hline \multicolumn{1}{|c|}{ Traditional performance evaluation methods } & \multicolumn{1}{c|}{ Modern performance evaluation methods } \\
\hline Based on cost/efficiency & Value-based \\
\hline Evaluate the results & Evaluate the results and its causes \\
\hline Profit-oriented & Customer-oriented \\
\hline Short-term orientation & Long-term orientation \\
\hline Prevalence of individual measures & Prevalence of team measures \\
\hline Prevalence of functional measures & Prevalence of transversal measures \\
\hline Comparison with standard & Improvement monitoring \\
\hline Aim at evaluating & Aim at evaluating and involving \\
\hline
\end{tabular}

Source: De Toni Toncia, 2001

When analysing the modern performance evaluation methods, it is worth to mention the advantages of nonfinancial indicators that are highlighted in the research literature (see Table 3). Lau and Sholihin (2005) state that financial indicators reach interested parties too late, information is too generalised and one-dimensional. Since financial indicators have historic nature are not detailed enough, they are only relevant in a short-term perspective. Kotane and Kuzmina (2011) have the similar opinion arguing that company's performance analysis that is based on barely evaluation of financial indicators provide insufficient information. The latter thought is based on the fact that financial indicators cannot evaluate impact of actions that are made today, since it takes time until impact of taken decisions is reflected in the financial results. Milost (2013) observes that financial performance indicators which are based on traditional record information do not indicate the real business performance picture and are not a proper base to make certain future-related decisions. In fact, financial results indicate the consequences of decisions taken in the past in numerical expression, however, they do not unfold causal factors that could lead to the given results and that could be followed when taking appropriate decisions in the future perspective.

Table 3. The advantages of non-financial performance indicators compared to financial indicators

\begin{tabular}{|l|l|}
\hline \multicolumn{1}{|c|}{ Financial indicators } & \multicolumn{1}{c|}{ Non-financial indicators } \\
\hline Reflect decisions made in the past & Reflect decisions made during the current period \\
\hline Aggregated performance information & Details of the current position and growth potential \\
\hline Short-term perspective & Long-term perspective \\
\hline Do not disclose causal relations & Disclose causal relations \\
\hline Sensitive to external factors & Reflect the impact of internal factors \\
\hline
\end{tabular}

Source: made by the authors based on Ittner et al., 2000, Lau et al., 2005, Kotane et al., 2011, Milost, 2013 


\section{The International Journal}

ENTREPRENEURSHIP AND SUSTAINABILITY ISSUES

ISSN 2345-0282 (online) http://jssidoi.org/jesi/

2018 Volume 6 Number 1 (September)

http://doi.org/10.9770/jesi.2018.6.1(10)

Before taking certain decisions, it is important that business managers, who intend to pursue strategic goals, foresee the impact that the decisions will have on the future results and timely make corrections when noticing that performance results tend to go to the wrong direction. Since non-financial indicators are more sensitive for the impact of today's decisions, it is expected that decision impact will be reflected earlier in non-financial results than in financial indicators. Research shows that non-financial performance indicators positively affect financial performance results and non-financial indicators are better indicators for future financial results than historic financial data. Moreover, non-financial indicators reflect company's economic position and growth possibilities better than financial company performance indicators provided in the reports (Kotane et al., 2011). As well, it is worth noting that financial results depend not only on how company performs its activity, but they are also responsive to the impact of external factors. To achieve the best performance results, managers must know how much of success is impacted by their actions and whereto they must add more efforts to improve results. Since non-financial indicators are less sensitive to external factors, they do better reflect the impact of the actions, which are taken in the company, on its success and can provide more detailed information about the effect of taken decisions on final results (Ittner et al., 2000).

Milost (2013) notices that for taking future decisions the economists perceive increasingly the inappropriateness of traditional record information; therefore, an increasing interest in the non-financial performance indicator systems is observed. Certainly, a majority of the authors in the literature agree on that in the performance evaluation one cannot rely barely on non-financial information and it has to be evaluated together with the financial indicators, since it merely supplements the financial information by explaining certain relationships that are not explained in traditional record (Cardinaels et al., 2010; Milost, 2013; Kotane, 2015; Ahmad et al., 2016).

\section{Comparison of modern company performance evaluation methods}

After conducting research literature analysis on the topic of business evaluation systems (Tangen, 2004, Gimžauskienè, 2007, Christauskas et al., 2009, Cardinaels et al., 2010, Adomavičiūtè, 2011, Peleckis et al., 2013, Bajus et al., 2014, Makutėnaitė et al., 2014, Bititci, 2015, Kučinskienė et al., 2015, Bhasin, 2017, Chouhan, 2017), the authors suggest the classification scheme of performance evaluation methods (see Figure 1), where the methods are classified into smaller groups according to method contents and performance evaluation purpose. According to this scheme, performance evaluation methods are first of all classified into traditional and modern ones. Traditional performance evaluation methods, as it was mentioned earlier, include analysis of financial performance results and their relative values. In the opinion of the authors of this paper, modern evaluation methods have to be split up into the following six groups of methods:

1. Performance record (accounting) methods. It is accounting data-based performance evaluation methods that calculate the financial value created by performance.

2. Quality management concept methods. It is performance evaluation methods that are based on the conception of total quality management. The purpose of these methods is to evaluate how the companies keep up with the requirements, what progress they do when improving their performance, and similar.

3. Causal relationship theory models. It is performance evaluation models that distinguish the main factors which affect the successful performance.

4. Business process evaluation models. It is models that emphasize processes during performance evaluation. The purpose of these models is to evaluate economy of performance and efficacy during the separate steps of the process.

5. Balanced system models. They are overall models of performance evaluation that are closely related to company's vision and strategy. They involve both financial and non-financial performance evaluation indicators and reflect the results in different performance perspectives. 
6. Multicriteria methods. It is complex performance evaluation methods that join many relevant performance indicators into a single summarising performance estimator.

Following the above-mentioned research papers, it is observed that out of all performance evaluation methods that are distinguished in the classification scheme, the most popular and most widely employed are the following ones: economic value added (EVA), balanced scorecard (BSC), performance prism, performance pyramid, six sigma, and multicriteria performance measurement.

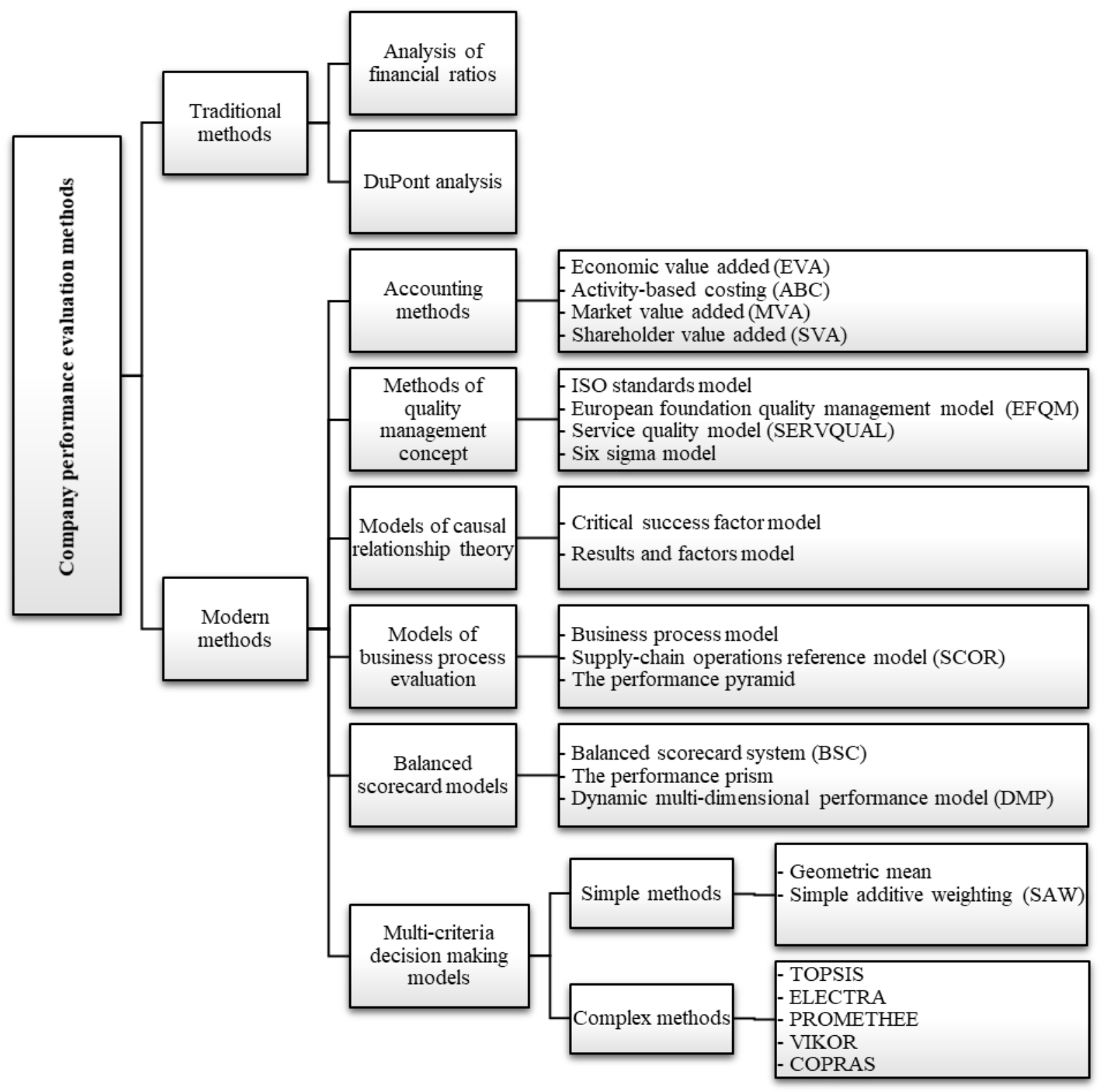

Fig.1. Classification scheme for performance evaluation methods

Source: made by the authors based on Tangen, 2004, Gimžauskienè, 2007, Christauskas et al., 2009, Cardinaels et al., 2010, Adomavičiūtè, 2011, Peleckis et al., 2013, Bajus et al., 2014, Makutėnaitė et al., 2014, Bititci, 2015, Kučinskienė et al., 2015, Bhasin, 2017, Chouhan, 
Economic value added (EVA) method that was created in 1990 by consultant company "Stern Stewart \& Co." is one of the most widely used financial indicators which allows evaluating company performance in a generalised way (Adomavičiūtè, 2011) and which with increasing frequency is applied in global companies as the main performance result evaluation measure (Makutenaite et al., 2014). The EVA method is substantiated by accounting data and is calculated as a difference between net operating profit after taxes and cost of invested capital:

$E V A=N O P A T-I C \times W A C C$,

here NOPAT - net operating profit after taxes

IC - invested capital

WACC - weighted average capital cost.

The EVA indicator shows, whether company's income was larger than the expected expenditures and capital costs during the analysed period. The higher value of the indicator shows better performance results; this increases the possibility of paying out larger dividends and higher stock market price (Bhasin, 2017). EVA fosters the efficient usage of the capital - both borrowed one and the private (Makutenaite et al., 2014). This method allows evaluating economic profit, quality of evaluation decisions and performance of all managers and employees. This enables determining creation of value for future periods as well as motivating staff. It is worth mentioning that this method can be applied not only for the entire company, but also for its single department, production line or a smaller production unit, confirming the contribution of each business chain unit when creating value of the company.

Balanced scorecard (BSC) was created in 1992 by two researchers of Harvard University, namely R. S. Kaplan and D. P. Norton. It is a multi-dimensional system, the purpose of which is to describe, implement and manage the strategy of the company in all its levels (Christauskas et al., 2009). According to Adomavičiūtè (2011), it is a performance evaluation model which allows, by using the causal relationship concept, connecting performance indicators with receivable benefits and ensures transformation of the strategy to specific goals and actions. The core of the BSC method is grouping of the key performance indicators that are related to company's strategy into four perspectives which provide answers to the following significant questions (Kaplan et al., 1996):

- Finances: how the company should look like to its shareholders that the financial success would accompany it.

- Clients: how the company has to look like to its clients that its vision would be implemented.

- Internal processes: which business processes the company should improve that it would satisfy its shareholders and clients.

- Learning and growth: how the company will keep the ability to change and improve itself that its vision would be implemented.

So, BSC allows presenting financial and non-financial performance indicators together: first ones as grouped into a single financial perspective and latter ones as grouped into a client perspective, internal processes perspective, and learning and growth perspective (Cardinaels et al., 2010). In the opinion of the authors of this method, nonfinancial indicators by a huge extent determine financial performance results. 
The International Journal

ENTREPRENEURSHIP AND SUSTAINABILITY ISSUES

ISSN 2345-0282 (online) http://jssidoi.org/jesi/

2018 Volume 6 Number 1 (September)

http://doi.org/10.9770/jesi.2018.6.1(10)

This method received a huge attention of companies worldwide and regarding its advantages became a popular tool of performance evaluation and strategic management. A close relationship of performance indicators with performance vision and strategy is considered to be the key advantage of the method. Since the system of balanced scorecard connects the most significant internal and external performance indicators, the strategy of the company is transmitted in a clear and understandable way for the all staff members; this motivates employees to achieve the goals of the company. Moreover, since the questions that are raised by the BSC system perspectives are focused on the future, this method acquires an advantage against other methods which are substantiated only by historical data. In any case, the problem of constructing a set of key indicators is highlighted in the research literature, as it is not unambiguously decided which specific indicators have to be analysed so that the best result of the system would be achieved. Therefore, the implementation and realisation of the system becomes to a complex process of a company that requires a lot of time and knowledge, and often huge finances.

Performance prism model was created in 2001 by the researchers of Great Britain A. Neely, C. Adams and M. Kennerly. Its purpose is to evaluate company's performance through five perspectives: strategies, possibilities, processes, satisfaction and contribution of interested groups. According to Chrisauskas et al. (2009), the model is unique in distinguishing the area of evaluation that was not distinguished in previous models, namely the contribution of interested groups to company's success.

The authors of the model provide explanations of each perspective (Neely et al., 2002). The first perspective, satisfaction of interested parties, should answer who the interested individuals of the company are and what their needs are. Consumers, employees, suppliers, investors, among others, can be interested parties; and one of the main objectives of a company is to create value for them. The other significant perspective, contribution of interested parties, should answer what company needs are from the point of view of interested groups. When creating value for interested individuals, the feedback is important for the company, e.g., loyalty, profitability, productivity, creativity, etc. When having the answers to the latter questions, the third perspective of the performance prism, called strategies, is important. The question raised to this perspective deals about what company's strategy should be so that needs and expectations of both interested parties and company itself would be satisfied. Furthermore, when the strategy is defined, one can switch to the perspective of processes, where decisions on which processes are needed for implementation of the strategy are taken. Finally, the perspective of possibilities should answer which abilities (groups of people, practice, technologies, infrastructure, etc.) are needed for the company so that implementation of processes would as productive as possible. So, the structure of the model indicates that when defining performance tools, it is incorrect to barely follow the strategy; first of all, needs and expectations of interested parties must be purged (Neely et al., 2002).

The fact the performance prism model distinguishes a unique area of evaluation, namely the contribution of interested groups to organisational success, is considered to be the main advantage of the model. In this way, when evaluating business performance, all interested parties are concerned. Moreover, the requirement to discuss and substantiate the organisational strategy and only afterwards choose performance evaluation indicators is considered to be a no less important strength of the model. Despite of these advantages of the model, two main disadvantages are indicated in the research literature. First of all, it is argued that in the existing company performance evaluation system the application of this model is difficult; therefore, it must be implemented as a separate system. Moreover, similarly to the most of other evaluation methods, the performance prism does not evaluate all organisational success factors.

Performance evaluation pyramid was suggested in 1989 by the authors of the USA K. F. Cross and R. L. Lynch. It is a system, the purpose of which is to connect the organisational strategy with its activities (Tangen, 2004). When applying this method, the goals for implementing the company's vision are raised for each hierarchical level from top down to bottom and the measures for reaching these goals are defined from bottom up 
The International Journal

ENTREPRENEURSHIP AND SUSTAINABILITY ISSUES

ISSN 2345-0282 (online) http://jssidoi.org/jesi/

2018 Volume 6 Number 1 (September)

http://doi.org/10.9770/jesi.2018.6.1(10)

to top. According to Adomavičiūtè (2011), it is beneficial when defining how organisational goals communicate ranging downwards and how the measures can make impact when going upwards by different levels of the organisation.

In the opinion of Tangen (2004), when forming the performance evaluation pyramid, first of all, company's strategy and vision must be defined. In the second hierarchical level, company's vision is transformed to the goals of business units, which are formed as short-term ones and are related to company's profitability and cash flows, and long-term ones, which are related to the growth and position in the market. To achieve these goals, the goals in the third hierarchical level are related to magnification of client satisfaction, flexibility and productivity. Finally, in the fourth level of the pyramid, business operation system indicators are split up to indicators of work centres, observed day by day: the quality, delivery, production cycle time and costs.

Such a hierarchical view to performance evaluation, which is related to the analysis of processes, is considered as one of the main advantages of performance evaluation pyramid. The other strength of this method is the integrity of business goals to the observed performance result indicators. Unfortunately, it is not defined which specific indicators should be observed when applying this method, therefore, the problem of identification of a set of performance indicators pyramid appears in the performance evaluation.

The method of six-sigma was created in 1986 in "Motorola" company in order to solve quality problems. It is worth noting that the title of this method, six sigma, means that there is 3.4 defects out of one million produced items; this does not make even 0,001 per cent, so it means that it is a nearly ideal process of production. Drohomeretski et al. (2014) explain that it is a business improvement strategy by which one seeks to identify and eliminate disadvantages of business processes and the reasons of mistakes, by concentrating attention to performance related to satisfaction of consumer needs. Gupta (2005) states that the majority of evaluation systems are strategic and do not go down to process management; meanwhile, the six-sigma method was created in order to evaluate all work aspects of an organisation. This system, which embodies leadership and management, consistently combines purchases and production, promotes services and sales, supports mastership of employees, introduction of innovations and comprehensive progress (Gupta, 2005).

The practical application of the six-sigma method is based on the methodology of five phases: definition, measurement, analysis, improvement and control (DMAIC) (Gupta, 2005, Mast et al., 2012). During the first step, definition, the problem must be clearly defined, i.e., including client expectations, company goals, teams and their responsibilities, resources, process and the lowest boundary of efficiency of the process. Furthermore, in the phase of measurement, the defined problem is presented in a measurable form, i.e., indicators, which are proper for measurement, are distinguished; data is collected; as well as means, standard deviations, etc. are calculated by using statistical methods. In this way, the results of current performance are evaluated and the goals for improvement of performance results are raised. Having the necessary information, the analysis is conducted. In this phase, the attention is focused on search of the essential impact factors and reasons which determine bad work or production quality results (defects). When this is clarified, in the phase of improvement, by doing testing one seeks to find out decisions for improvement of processes so that defects are eliminated. Finally, the phase of control is reached where the improved processes must be controlled and the six sigma initiative must be maintained, so if deviations and increasing number of defects are noticed, one should again return to the phase of definition and to repeat the cycle once again.

One of the advantages of this method is efficiency when saving funds of an organisation; one should only need to detect defects in time and take actions for the process of their elimination. The six sigma method is increasingly introduced in companies; it is liked because of a clear and universal system. Moreover, the significant particularity of the system is namely evaluation of all aspects of organization and application of statistical 
The International Journal

ENTREPRENEURSHIP AND SUSTAINABILITY ISSUES

ISSN 2345-0282 (online) http://jssidoi.org/jesi/

2018 Volume 6 Number 1 (September)

http://doi.org/10.9770/jesi.2018.6.1(10)

methods when evaluating its performance. It is also stated that this method acquires an advantage against other methods, since it has a strong focus on the satisfaction of client needs. Unfortunately, this advantage raises a threat that the significant quality control indicators might be uninvolved in the evaluation. Besides, as it is common for the majority of performance evaluation methods, the problem of a set of observed performance indicators is considered to be the main disadvantage of the method, since it is not defined which specific indicators must be observed.

The purpose of the model of multicriteria company performance measurement is to complexly evaluate company's performance results, taking into account the majority of significant performance indicators. In the research literature, it is observed that when conducting performance result evaluation by following analysis of a few significant indicators, the conclusion making and decision making can become to some extent chaotic: the value of one indicator can be better, the value of other indicators can be worse, however, at the end it is complicated to define, whether the performance result improved or deteriorated. For this reason, in the opinion of Peleckis et al. (2013), multicriteria performance evaluation methods can be applied, since they join single performance indicators into a single summarising indicator, which can be additive or a multiplicative combination of partial indicators. Tamašiūnienè et al. (2006) indicate that these methods can be classified into two groups: simple methods (geometric average, simple additive weighting (SAW), sum of units) and complex methods (TOPSIS, ELECTRA, PROMETHEE, VIKOR, complex proportional one, simplified complex one, etc.). It is worth noting that performance results often do not match when different methods are applied; therefore, it is suggested to construct a multicriteria evaluation model out of a few multicriteria methods (Stonkute et al., 2016). Universality of the model is considered to be its essential advantage. The model allows evaluating quantitatively any complex phenomena that is expressed by many indicators. It is significant to evaluate as many indicators as possible so that the threath of missing important company performance evaluation aspects would be eliminated. Peleckis et al. (2013) suggest joining the analysied factors into certain groups, e.g., by distinguishing indicators of profitability, cost level, efficiency of asset employment, and usage of labour force. The universality of the model is as well expressed in that each company can adjust it according to its needs and goals of evaluation. The model involves a wide spectrum of evaluation indicators and requires much of efforts when collecting information and choosing proper multicriteria methods during construction of the model. It is observed that the identification of factor significance by determining their weights becomes a complex task. This is the reason why a company may experience huge time and financial costs.

Table 4. Comparison of modern company performance evaluation methods

\begin{tabular}{|c|c|c|c|c|c|c|c|}
\hline Criteria & 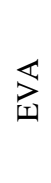 & $\underset{\mathscr{n}}{U}$ & 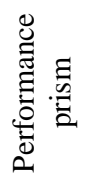 & 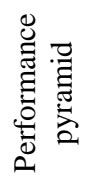 & $\begin{array}{l}\underset{\tilde{E}}{\tilde{E}} \\
\cdot \vec{\omega} \\
\ddot{n} \\
\ddot{n}\end{array}$ & 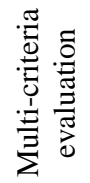 & 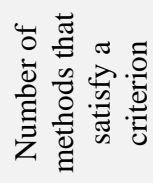 \\
\hline Quantitative evaluation & + & + & + & + & + & + & 6 \\
\hline Qualitative evaluation & - & + & + & + & - & $+/-$ & $3(4)$ \\
\hline Non-financial indicators are included & - & + & + & + & + & $+/-$ & $4(5)$ \\
\hline Specific indicators are measured & + & - & - & - & - & - & 1 \\
\hline Activity evaluation is generalized & + & - & - & - & - & + & 2 \\
\hline Linked to the company's strategy & - & + & + & + & - & $+/-$ & $3(4)$ \\
\hline A look forward to the future & + & + & + & + & - & $+/-$ & $4(5)$ \\
\hline Simple, low cost & + & - & - & - & - & - & 1 \\
\hline Meeting customers' needs & - & + & + & + & + & $+/-$ & $4(5)$ \\
\hline Employee motivation & - & + & + & + & + & $+/-$ & $4(5)$ \\
\hline Process analysis & - & + & + & + & + & $+/-$ & $4(5)$ \\
\hline Number of criteria the method satisfies & 5 & 8 & 8 & 8 & 5 & 2(9) & \\
\hline
\end{tabular}


To summarise the review of company performance evaluation methods, the comparison of the methods is conducted following the criteria of the company performance evaluation systems that are distinguished by the authors of this paper (see Table 4). It can be concluded that there is no single performance evaluation method that would be the most fitable to all companies; the choice depends on the organisational needs and evaluation goals. It is observed that all performance evaluation methods are based on the quantitative evaluation, however, specific indicators that must be measured for evaluating performance results are provided in the EVA method exclusively, which does not involve non-financial information. For this reason, when choosing methods that involve nonfinancial indicators into evaluation, the challenge of forming a set of indicators is faced; this determines a complex, time consuming and finance requiring introduction of the method to organisational management system. On the other hand, contrary to the traditional financial performance evaluation methods, in the majority of the modern methods, satisfaction of client needs, employee motivation and perspectives of process analysis are distinguished; this allows evaluating performance results complexly. It is worth noting that the system of balanced scorecard, performance prism and performance evaluation pyramid satisfies most of the criteria needed for the complex performance evaluation: it relates performance evaluation and the required indicators with the organizational strategy so that this allows evaluating factual results and, focusing to the future, taking management decisions that will help achieving long-term goals of the company. In the opinion of the authors of this paper, it is worth drawing attention to the method of multicriterial performance evaluation, which, as compared to the other methods, is the most universal, satisfying from two to nine criteria needed for the complex performance evaluation, and which is especially flexible, when considering organizational needs and evaluation goals.

\section{Conclusions}

In the research literature, a company's performance evaluation is defined as a wide and multifunctional process which joins all its significant performance indicators in a way that allows it evaluating performance, enables a constant company management process, value creation, adjustment, and fast reaction that leads to improvement and growth of the company.

Research literature allows distinguishing the key advantages of non-financial indicators as opposed to financial indicators. The non-financial indicators may reflect the effect of currently made decisions, they unfold causal relationships between factors and final results, provide detailed information about company's current position and growth possibilities. The non-financial indicators are closely related with the long-term goals of an organization, so they are better indicators of the financial results in the future. It is worthy to note that the nonfinancial information is considered to be a compliment of the financial information; therefore, company's performance evaluation should not focus on barely financial indicators.

A company's performance evaluation methods can be grouped into two categories: traditional methods that are justified only by the analysis of financial indicators and modern ones that combine the company's financial and non-financial performance information and allow evaluating its activity both quantitatively and qualitatively. The most popular modern company's performance evaluation models are considered the following ones: economic value added method, balanced scorecard, activity prism, activity evaluation pyramid, six sigma model and multicriteria model.

There is no single performance evaluation method that would be appropriate for all companies; the method should be chosen individually considering the aim of the evaluation and the needs of the company. 
There can be established a multi-criteria performance evaluation model that would satisfy the needs of a particular business' activity and targets for evaluation. So the further research can be targeted at establishing model like this for manufacturing companies by identifying a set of specific key performance indicators and their impact on performance results.

\section{References}

Abdel-Maksoud A., Dugdale D., Luther R. (2005). Non-financial performance measurement in manufacturing companies. The British Accounting Review. Vol. 37, p. 261-297. https://doi.org/10.1016/j.bar.2005.03.003

Adomavičiūtè D. (2011). Muitinès audito modelis verslo įmonių veiklos vertinimui: daktaro disertacija [Customs Audit Model for Evaluation of Business Activities: Doctoral Dissertation]. p. 76-90. Vilnius: Vilniaus universitetas, Socialiniai mokslai, Vadyba ir administravimas.

Ahmad K., Zabri S. M. (2016). The effect of non-financial performance measurement system in firm performance. International Journal of Economics and Financial Issues. Vol. 6 (S6), p. 50-54. Retrieved from: https://www.researchgate.net/publication/309008537

Bhasin M. (2017). A study of economic value added disclosures in the annual reports: is EVA a superior measure of corporate performance? East Asian Journal of Business Economics. Vol. 5 (1), p. 10-26. https://doi.org/10.20498/eajbe.2017.5.1.10

Bititci U. S. (2015). Overview of popular performance measurement models and frameworks. Managing Business Performance: The Science and the Art. p. 251 - 262. Padstow: TJ International Ltd. https://doi.org/10.1002/9781119166542

Cardinaels E., van Veen-Dirks P. M. G. (2010). Financial versus non-financial information: The impact of information organization and presentation in a Balanced Scorecard. Accounting, Organizations and Society. Vol. 35, p. 565-578. https://doi.org/10.1016/j.aos.2010.05.003

Choong K. K. (2013). Understanding the features of performance measurement system: a literature review. Measuring Business Excellence. Vol. 17 (4), p. 102-121. https://doi.org/10.1108/MBE-05-2012-0031

Chouhan V., Soral G., Chandra B. (2017). Activity based costing model for inventory valuation. Management Science Letters. Vol. 7 (3), p. 135-144. doi:10.5267/j.msl.2016.12.003

Christauskas Č., Kazlauskienè V. (2009). Modernių veiklos vertinimo sistemų ịtaka ịmonès valdymui globalizacijos laikotarpiu. $\begin{array}{lllllll}\text { Ekonomika } & \text { ir } & \text { vadybar } & 14, & \text { p. } & 715-722 . & \text { Retrieved }\end{array}$ http://verslokelias.eu/resursu_katalogas/content/article/kitos\%20publikacijos/2\%20kitos\%20publikacijos\%20nr\%204.pdf

De Toni A., Tonchia S. (2001). Performance measurement systems - Models, characteristics and measures. International Journal of Operations \& Production Management. Vol. 21 (1/2), p. 46-71. https://doi.org/10.1108/01443570110358459

Drohomeretski E., Costa S. E. G., Lima E. P., Rosa Garbuio P. A. (2014). Lean, six sigma and lean six sigma: an analysis based on operations strategy. International Journal of Production Research. Vol. 52 (3), p. 804-824. https://doi.org/10.1080/00207543.2013.842015

Europos Parlamento ir Tarybos direktyva 2014/95/ES. Europos Sajungos oficialusis leidinys, L 330. Nr. 57, p. 1-9, 2014. Retrieved from: http://data.europa.eu/eli/dir/2014/95/oj

Franceschini F., Galetto M., Turina E. (2013). Techniques for impact evaluation of performance measurement systems. International Journal of Quality \& Reliability Management. Vol. 30 (2), p. 197-220. https://doi.org/10.1108/02656711311293599

Gimžauskienė E. (2007). Organizacijų veiklos vertinimo sistemos: monografija. [Organizations’ evaluation systems: monograph] Kaunas: Technologija

Gupta P. (2005). Šešios sigmos verslo sėkmei valdyti [Six Sigma for Business Success Management]. Vilnius: Vaga. 
Ittner C., Larcker D. (2000). Non-financial performance measures: what works and what doesn't. Knowledge@Wharton. The Wharton School, University of Pennsylvania. Retrieved from: http://knowledge.wharton.upenn.edu/article/non-financial-performance-measureswhat-works-and-what-doesnt/

Jasiukevičius L., Christauskas Č. (2011). The Application of performance measurement system at the electricity sector of Lithuania. Inžinerinė Ekonomika. Nr. 22 (3), p. 283-291. https://doi.org/10.5755/j01.ee.22.3.518

Kaplan R. S., Norton D. P. (1996). Using the Balanced Scorecard as a Strategic Management System. Harvard Business Review. Vol. 74 (1), p. 75-85.

Klovienė L. (2012). Veiklos vertinimo sistemos adekvatumas verslo aplinkai: daktaro disertacijos santrauka. Kaunas: Kauno technologijos universitetas, Socialiniai mokslai, Vadyba ir administravimas.

Kotane I. (2015). Evaluating the importance of financial and non-financial indicators for the evaluation of company's performance. Management Theory and Studies for Rural Business and Infrastructure Development. Vol. 37, No. 1, pg. 80-94. https://doi.org/10.15544/mts.2015.08

Kotane I., Kuzmina-Merlino I. (2011). Non-financial indicators for evaluation of business activity. European integration studies. Research and Topicalities. No. 5, p. 213-219. Retrieved from: http://www.eis.ktu.lt/index.php/EIS/article/view/1099/

Kotane[ I., Kuzmina-Merlino I. (2012). Assessment of financial indicators for evaluation of business performance. European integration studies. Research and Topicalities, No. 6, p. 216-224.Retrieved from: http://www.eis.ktu.lt/index.php/EIS/article/view/1554/1597

Kučinskienė M., Fominienė A. (2015). Kompleksinis požiūris ị viešojo valdymo institucijų veiklos vertinimą [Complex approach to evaluation of activity of public organizations]. Accounting, Audit, Analysis: Science, Studies and Business Synthesis. p. 151-165. Vilnius: Vilniaus universiteto leidykla

Lau C. M., Sholihin M. (2005). Financial and nonfinancial performance measures: How do they affect job satisfaction? The British Accounting Review. Vol. 37, p. 389-413. doi:10.1016/j.bar.2005.06.002

Lynch R. L., Cross K. F. (1991). Measure Up! Yardsticks for continuous improvement. Cambridge: Basil Blackwell.

Makutėnaitė J., Gliaubicas D., Makutėnienè D. (2014). Ekonominès pridėtinès vertès metodo tinkamumas ịmonès vertei nustatyti [The appropriateness of the economic added value method for determining the company's value]. Apskaitos ir finansu mokslas ir studijos: problemos ir perspektyvos. Nr. 1 (9), p. 137-145. https://doi.org/10.15544/ssaf.2014.15

Mast J., Lokkerbol J. (2012). An analysis of the Six Sigma DMAIC method from the perspective of problem solving. International Journal of Production Economics. Vol. 139 (2), p. 604-614. https://doi.org/10.1016/j.ijpe.2012.05.035

Milost F. (2013). Information power of non-financial performance measures. International Journal of Business Management and Economic Research. Vol. 4 (6), p. 823-828. Retrieved from: http://www.ijbmer.com/vol4issue6.php

Modi S. (2016). A review on the literature of value relevance of nonfinancial variables or information. International Journal of Advance Research in Computer Science and Management Studies. Vol. 4 (2), p. 81-85. Retrieved from: http://www.ijarcsms.com/February2016.htm

Moullin M. (2007). Performance measurement definitions: Linking performance measurement and organisational excellence. International Journal of Health Care Quality Assurance. Vol. 20 (3), p. 181-183. https://doi.org/10.1108/09526860710743327

Najmi M., Kehoe D. F. (2001). The role of performance measurement system in promoting quality development beyond ISO 9000. International Journal of Operations \& Production Management. Vol. 21 (1/2), p. 159-172. https://doi.org/10.1108/01443570110358512

Neely A., Adams C., Kennerley M. (2002). The performance prism: the scorecard for measuring and managing business success. Financial Times Series. Financial Times/Prentice Hall.

Peleckis K., Krutinis M., Slavinskaitè N. (2013). Daugiakriterinis alkoholio pramonės įmonių pagrindinės veiklos efektyvumo vertinimas. [Multivariate assessment of the main activities of the alcohol industry], Verslo ir teisès aktualijos. Nr. 8, p. $1-16$. https://doi.org/10.5200/1822-9530.2013.1 
The International Journal

ENTREPRENEURSHIP AND SUSTAINABILITY ISSUES

ISSN 2345-0282 (online) http://jssidoi.org/jesi/

2018 Volume 6 Number 1 (September)

http://doi.org/10.9770/jesi.2018.6.1(10)

Slatkevičienė G., Vanagas P. (2001). Veiklos kompleksinio vertinimo sistema: sudarymo teorija ir metodai: monografija [Veiklos kompleksinio vertinimo sistema: sudarymo teorija ir metodai: monografija]. Kaunas: Technologija.

Stonkute E., Tamulevičienė D. (2016). Daugiakriterinio vertinimo modelio taikymas nustatant statybos įmonių grupių finansinę būklę. [Application of multicriteria assessment model for determining the financial condition of construction companies]. VU EF studentu mokslinės draugijos konferencjos straipsnių rinkinys 2016. p. 250-259. Vilnius: Vilniaus universiteto leidykla.

Tamošiūnienė R., Šidlauskas S., Trumpaitė I. (2006). Investicinių projektų efektyvumo daugiakriterinis vertinimas. Verslas: Teorija ir Praktika. Vol. 7 (4), p. 203-212.

Tangen, S. (2004). Performance measurement: from philosophy to practice. International Journal of Productivity and Performance Management. Vol. 53 (8), p. 726-737. https://doi.org/10.1108/17410400410569134

Жегалина А. С. (2016). Достоинства и недостатки сбалансированной системы показателей [Advantages and disadvantages of a balanced system of indicators]. Economic Theory and Business Process. Vol. 10 (19), p. 31-32.

Judita NARKUNIENĖ, MSC in Business Economics, Vilnius University, Faculty of Economics and Business Administration, Business Department. Research interests: business finance, business process management, strategic management, company performance evaluation, econometric analysis.

ORCID ID: orcid.org/0000-0002-9880-1003

Aurelija ULBINAITÉ is an Associate Professor at Vilnius University, Faculty of Economics and Business Administration, Business Department, from where she received her PhD degree in Management and Administration, Social Science, in 2012. Since 2013, she is a member of the Lithuanian Society of Young Researchers. Her teaching curriculum involves Business Diagnostics, Business Integrational Processes, Business Operation Seminar, Service Process Management, International Trade of Services, and Insurance Process Management. She has participated in research projects funded by Taiwan's Ministry of Foreign Affairs, Taiwan's Ministry of Education, and the Estonian Institute. Research interests: business process management, company performance evaluation, decision making, consumer behaviour, risk management and insurance, service industry, service marketing, European and Asian socio-economic and cultural values.

ORCID ID: orcid.org/0000-0001-5025-7240

Register for an ORCID ID:

https://orcid.org/register

Copyright (C) 2018 by author(s) and VsI Entrepreneurship and Sustainability Center

This work is licensed under the Creative Commons Attribution International License (CC BY).

http://creativecommons.org/licenses/by/4.0/

C. (i) Open Access 